\title{
Pengaruh Penambahan Tepung Tapioka Terhadap Kualitas Dan Akseptabilitas Bakso Sapi
}

\author{
Salam N. Aritonang \\ Jurusan Produksi Ternak Fakultas Peternakan Universitas Andalas, Padang
}

\begin{abstract}
The research was aimed to evaluate the effect of using cassava starch on the quality and acceptability of meatball. Six kilograms of ground beef meat which have been well mixed with spices of salt, garlic and pepper were divided into 5 sub-groups. Each sub-group of dough was mixed with 5 different levels of cassava starch of $0 \%\left(R_{0}\right), 5 \%\left(R_{1}\right), 10 \%$ $\left(R_{2}\right), 15 \%\left(R_{3}\right)$ and $20 \%\left(R_{4}\right)$, respectively. The dough were then made in small ball form (meatball) and subdivided into 4 sub-sub-groups as replications. The raw dough of meat ball was then cooked in boiling water for 15 minutes to produce ready to eat meatball products. The products were measured for $\mathrm{pH}$, moisture and protein content, and acceptability. Results indicated that $\mathrm{pH}$, moisture and protein content of the meatball were decreased significantly $(P<0,01)$ by increasing the use of cassava starch. Acceptability of meatball by test consumers, however, was not significantly affected by the use of cassava starch. Therefore, cassava starch could be used up to $20 \%$ in making meat ball.
\end{abstract}

Key words: cassava starch, meatball, acceptability.

\section{Pendahuluan}

Daging merupakan bahan makanan yang mengandung protein hewani tinggi, yang sangat berguna untuk pertumbuhan mulai dari balita, anak - anak, remaja maupun dewasa. Oleh karena zat makanan yang dikandungnya tinggi, diikuti keasaman yang mendekati normal, membuat daging menjadi suatu media yang disukai untuk pertumbuhan mikroorganisme.

Kontaminasi oleh mikroorganisme dapat mempercepat kerusakan pada daging, yang bisa terjadi mulai hewan disembelih, dikuliti, dipotong - potong hingga penanganan lebih lanjut (Forrest dkk, 1975). Kondisi seperti ini menyebabkan daging menjadi suatu bahan pàngàn yang mưuāh rusäăk dän tidāk dapat disimpan lama terlebih jika disimpan pada temperatur ruang
(Buckle et al, 1978). Untuk meningkatkan daya manfaatnya, daging sering diolah menjadi bentuk lain diantaranya bakso.

Bakso merupakan salah satu aneka jajanan yang cukup disukai oleh masyarakat Indonesia pada umumnya, dengan permintaan yang cukup tinggi dan bisa ditemukan direstoran besar, warung sederhana, hingga penjaja keliling. Pada prinsipnya komposisi bahan yang digunakan dalam pembuatan bakso adalah terdiri dari daging dalam keadaan segar, $\mathrm{NaCl}$ (garam), MSG, lada (Elviera, 1988 dan Purnomo, 1990). Dalam pembuatan semua bahan digiling bersama dalam suatu wadah, lalu dibentuk bulat - bulat untuk kemudian direbus dalam air mendidih selama 10-15 menit.

Tepung tapioka merupakan salah satu jenis tepung yang sering ditambahkan dalam pembuatan bakso. 
Menurut Somaatmajda (1984), sebagai bahan baku industri pangan tepung tapioka telah digunakan sebagai bahan pengisi atau bahan pengental, karena tepung tapioka mengandung unsur yang diperlukan oleh suatu bahan pengisi, yaitu unsur pati (amylum). Ditambahkan oleh Tjokroadikoesoemo dan Soebiyakto (1986), bahwa sifat tepung tapioka mirip dengan Amilopektin yaitu : (1) Dalam bentuk pasta Amilopektin menunjukkan penampakan yang sangat jernih sehingga dapat meningkatkan mutu penampilan dari produk akhir. (2) Pada suhu normal, pasta pada Amylopektin tidak mudah menggumpal dan kembali menjadi keras. (3) Memiliki daya perekat tinggi sehingga pemakaian pati dapat dihemat. Adapun penggunaan tepung tapioka yang umum ditambahkan dalam pembuatan bakso menurut Sunarlim (1994) adalah sekitar $10 \%$.

\section{Metode Penelitian}

Penelitian ini berupa experimental, yang menggunakan $6 \mathrm{Kg}$ daging sapi yang sudah dibuang lemak dan uratnya, lalu digiling halus dan dibagi menjadi 20 bagian, kemudian dibagi menjadi 5 kelompok perlakuan secara acak. Rancangan yang digunakan adalah Rancangan Acak Lengkap yang terdiri dari 5 perlakuan dengan penggulangan 4 kali, perlakuan tersebut yaitu penambahan tepung tapioka sebanyak $0 \%$ $\left(\mathrm{R}_{0}\right), 5 \%\left(\mathrm{R}_{1}\right), 10 \%\left(\mathrm{R}_{2}\right), 15 \%\left(\mathrm{R}_{3}\right)$ dan $20 \%\left(R_{4}\right)$, kedalam daging yang sudah digiling halus dan dicampur dengan bumbu $(\mathrm{NaCl}$, bawang merah, bawang putih, lada). Setelah terbentuk adonan lalu dibentuk jadi bulat - bulatan untuk kemudian direbus dalam air mendidih selama 15 menit. Peubah yang diamati dalam penelitian ini adalah $\mathrm{pH}$, kadar protein, kadar air, dan akseptabilitas bakso sapi. Data yang dikumpulkan selanjutnya dianalisis dengan menggunakan metoda sidik ragam, sedangkan pengujian efek dari setiap perlakuan digunakan uji jarak berganda Duncan.

\section{Hasil Penelitian Dan Pembahasan}

pH

Peningkatan penggunaan tepung tapioka dalam pembuatan bakso nyata menurunkan $\mathrm{pH}$ bakso sapi. Hal ini tampak pada perlakuan $R_{4}$ yaitu bakso yang mengandung $20 \%$ tepung tapioka mempunyai $\mathrm{pH}$ paling rendah dibanding perlakuan lain, namun tidak berbeda nyata dengan $\mathrm{pH}$ bakso perlakuan $R_{3}$, yaitu yang mengandung $10 \%$ tepung tapioka.

Penurunan $\mathrm{pH}$ bakso sapi akibat peningkatan pertumbuhan tepung tapioka diduga karena menurut Deman (1997) sifat dari tepung tapioka diantaranya adalah dapat meningkatkan daya ikat air, dimana dengan semakin meningkat penggunaan tapioka maka air yang diikat pada produk pangan tersebut juga akan meningkat pula, sehingga akan menurunkan kandungan air dari produk tersebut yang diikuti pula dengan menurunnya $\mathrm{pH}$. Dengan demikian penambahan tepung tapioka dalam pembuatan bakso daging sapi dalam penelitian ini menghasilkan $\mathrm{pH}$ bakso sapi yang rendah.

\section{Protein}

Meningkatnya penggunaan tepung tapioka nyata menurunkan kandungan protein bakso sapi. Hal ini tampak pada perlakuan $R_{4}$ yaitu bakso daging sapi yang diberi $20 \%$ tepung tapioka kandungan proteinnya rendah diikuti oleh $R_{3}(15 \%), R_{2}(10$ $\%), R_{1}(5 \%)$, dan $R_{0}(0 \%)$. Menurunnya kandungan protein 
bakso daging sapi seiring dengan peningkatan tepung tapioka yang ditambahkan, disebabkan tepung tapioka berperan sebagai bahan pemadat sehingga meningkatkan volume dari bakso tersebut, seperti yang dikemukakan oleh Deman (1997) tepung tapioka sering digunakan dalam industri pangan sebagai bahan pengisi atau pengental dengan adanya unsur pati (amylum) yang dikandungnya. Dengan demikian meningkatnya volume bakso sapi akibat penambahan tapioka akan diikuti oleh menurunnya kandungan protein bakso sapi.

Air

Meningkatnya penggunaan tepung tapioka nyata menurunkan kandungan air bakso sapi. $\mathrm{Hal}$ ini tampak pada perlakuan $\mathbf{R}_{4}$ yaitu bakso sapi yang diberi $20 \%$ tepung tapioka, mengandung air yang paling rendah diikuti oleh bakso sapi yang ditambahkan $15 \%\left(\mathbf{R}_{3}\right), 10 \%\left(\mathbf{R}_{2}\right), 5$ $\%\left(R_{1}\right)$ dan $0 \%\left(R_{0}\right)$ tepung tapioka dản diantara masing - masing perlakuan satu sama lain saling berbeda nyata. Menurunnya kandungan air bakso sapi seiring dengan meningkatnya jumlah tepung tapioka yang ditambahkan dalam pembuatan bakso tidak lain disebabkan oleh fungsi dari tepung tapioka itu sendiri sebagai bahan pemadat. Seperti yang dikemukakan oleh Soemaatmadja (1984), bahwa tepung tapioka sering digunakan sebagai bahan baku industri pangan sebagai bahan pengisi atau bahan pengental, karena mengandung unsur yang diperlukan oleh suatu bahan pengisi yaitu unsur pati. Unsur pati ini menurut Tjokrodikoesoemo dan Soebiyakto (1986) selain dapat membentuk unsur padat, juga memiliki daya perekat yang tinggi. Itu sebabnya penambahan tepung tapioka dalam pembuatan bakso sapi dapat menurunkan kandungan airnya karena bahan pemadatnya meningkat.

\section{Akseptabilitas \\ Warna. Penggunaan berbagai level tepung tapioka tidak memberikan pengaruh yang nyata terhadap warna dari bakso sapi, di mana semua panelis memberikan nilai yang sama yaitu menyukai bakso daging sapi untuk semua perlakuan. $\mathrm{Hal}$ ini disebabkan sifat dari amylopektin yang dikandung dalam tapioka memberikan penampakan yang sangat jernih sehingga disukai karena dapat meningkatkan mutu dari produk akhir.}

Bau. Penggunaan berbagai level tepung tapioka tidak memberikan pengaruh yang nyata terhadap bau bakso daging sapi, di mana hampir semua panelis memberikan nilai yang sama yaitu menyukai bau bakso sapi untuk semua perlakuan. Ada juga yang memberikan penilaian netral justru pada bakso yang tidak ditambahkan tepung tapioka. Ini menunjukkan bahwa penambahan tepung tapioka dalam penelitian ini berfungsi sebagai bahan pemadat (Somaatmadja, 1984) tetapi tidak memberikan perubahan terhadap bau bakso sapi.

Rasa. Penggunaan berbagai level tepung tapioka juga tidak memberikan pengaruh yang nyata terhadap rasa bakso sapi, di mana penerimaan semua panelis terhadap rasa bakso sapi pada semua perlakuan hampir sama yaitu me-nyukainya. Ada juga yang memberikan nilai netral pada rasa bakso sapi yang ditambahkan $20 \%$ tepung tapioka $\left(\mathrm{R}_{4}\right)$. Ini menunjukkan bahwa tepung tapioka memang sudah umum digunakan dalam industri pangan karena cenderung tidak menimbulkan 
perubahan terhadap rasa produk yang dihasilkan (Tjokrodikoesoemo dan Subiyakto, 1986).
Secara keseluruhan hasil penelitian ini dapat dilihat pada tabel berikut ini

Tabel 1. Rangkuman Hasil Penelitian Pengaruh Penambahan Tepung Tapioka Terhadap Kualitas dan Akseptabilitas Bakso Sapi

\begin{tabular}{lccccc}
\hline \multirow{2}{*}{ Parameter } & \multicolumn{5}{c}{ Perlakuan } \\
\cline { 2 - 6 } & $\mathbf{R}_{\mathbf{0}}$ & $\mathbf{R}_{\mathbf{1}}$ & $\mathbf{R}_{\mathbf{2}}$ & $\mathbf{R}_{\mathbf{3}}$ & $\mathbf{R}_{\mathbf{4}}$ \\
\hline $\mathrm{pH}$ & 6,59 & 6,47 & 6,24 & 6,03 & 5,69 \\
Kadar Protein (\%) & 11,84 & 11,57 & 10,26 & 9,18 & $\mathbf{8 , 0 7}$ \\
Kadar Air (\%) & 64,74 & 63,56 & 62,18 & 60,89 & 59,06 \\
\hline Akseptabilitas : & & & & & \\
\hline Warna & Suka & Suka & Suka & Suka & Suka \\
Rasa & Suka & Suka & Suka & Suka & Netral \\
Bau & Netral & Suka & Suka & Suka & Suka \\
\hline \hline
\end{tabular}

Keterangan : Angka yang ditandai dengan huruf yang sama kearah baris menunjukkan tidak berbeda nyata

\section{Kesimpulan}

Penambahan tepung tapioka bakso sapi sangat nyata $(\mathrm{P}<0,01)$ menurunkan $\mathrm{pH}$, kadar protein dan kadar air, tetapi tidak mempengaruhi $(\mathrm{P}>0,05)$ akseptabilitasnya. Penggunaan tepung tapioka sampai $20 \%$ pada pembuatan bakso sapi masih dapat diterima oleh panelis.

\section{Daftar Pustaka}

Buckle, K.A dan R.A. Edwards. 1978. A Course Manual in Food Science. Wtson Ferguson dan Co. Brisbane.

Deman, J. M. 1997. Kimia Pangan. Penerbit ITB. Bandung.

Elviera, G. 1988. Pengaruh Pelayuan Daging Sapi Terhadap Mutu Bakso. Skripsi. Jurusan Teknologi Pangan dan Gizi Fateta, IPB. Bogor.
Forrest, J. C., E. D. Aberie, H. B. Henrich, M. D. Jugle and R. A. Maecel. 1975. Principle of Meat Science. W. H. Freeman and Co. San Fransisco.

Purnomo, H. 1990. Kajian Mutu Bakso Daging, Bakso Urat, dan Bakso Aci di Daerah Bogor. Karya ilmiah, Fateta IPB. Bogor.

Somaatmadja, D. 1984. Pemanfaatan Ubi Kayu dalam Industri Pertanian. Balai Besar penelitian dan Pengembangan Industri Hasil Pertanian. Departemen perindustrian. Bogor.

Sunarlim, R. 1994. Prosiding Seminar Nasional Sains dan Teknologi Peternakan. Pengolahan dan Komunikasi Hasil-Hasil Pertanian. Balai Penelitian Ternak Puslitbang Ciawi. Bogor. 
Tjokroadikoesoemo dan P. Ubikayu Lainnya. PT. Soebiyakto. HFS dan Industri Gramedia. Jakarta.

Alamat Korespondensi: Dr. Ir. Salam N. Aritonang

Jl. Kis Mangunsarkoro 11 Padang. 25129

HP. 08126701553

Alamat Kantor : Fakultas Peternakan Universitas Andalas

Kampus Limau Manis-Padang

Telp. 0751-74208 Fax: 0751-71464

Diterima: 6 Agustus 2007, Disetujui: 3 September 2007 